\title{
Strategi Pemimpin dalam Meningkatkan Mutu Pondok Pesantren Zulhijjah Muara Bulian
}

\author{
Khairunnas $^{1 *}$, Bawaihi ${ }^{2}, \&$ Nurmia $^{3}$ \\ Universitas Islam Negeri Sulthan Thaha Saifuddin, Jambi \\ *corresponding author: khairunas@uinjambi.ac.id
}

\begin{abstract}
:
This research aims to analyze the strategy of leaders in improving the quality of education in Zulhijjah Muara Bulian boarding school. This research uses descriptive qualitative methods. Data collection is done through observation, interviews, and documentation. Data analysis uses data reduction, data presentation, and drawing conclusions, and verification. The results showed kiai has four roles, in improving the quality of education, namely educators, administrators, managers, and supervisors. Improving the quality of education is done by pursuing the welfare of teachers and contributing thought to the progress of the region and able to become cadres of scholars who will lead the ummah in the future by maintaining educational inputs, processes, and outputs.
\end{abstract}

KEYWORDS: Quality of education; boarding school; leader strategy.

\begin{abstract}
ABSTRAK:
Penelitian ini bertujuan untuk menganalisis strategi pemimpin dalam meningkatkan mutu pendidikan di pondok pesantren Zulhijjah Muara Bulian. Penelitian ini menggunakan metode kualitatif deskriptif. Pengumpulan data dilakukan melalui observasi, wawancara, dan dokumentasi. Analisis data menggunakan reduksi data, penyajian data, serta menarik kesimpulan, dan verifikasi. Hasil penelitian menunjukkan kiai memiliki empat peran, dalam meningkatkan mutu pendidikan, yaitu edukator, administrator, manajer, dan supervisor. Peningkatan mutu pendidikan dilakukan dengan mengupayakan kesejahteraan guru dan memberikan sumbangsih pemikiran terhadap kemajuan daerah dan mampu menjadi kader-kader ulama yang akan memimpin umat di masa yang akan datang dengan mempertahankan input, proses, dan output pendidikan.
\end{abstract}

KATA KUNCI: Mutu pendidikan; pondok pesantren; strategi pemimpin.

Copyright @ Published by Program Studi Manajemen Pendidikan Islam Fakultas Tarbiyah dan Keguruan

Universitas Islam Negeri Sulthan Thaha Saifuddin jambi

Mendalo Darat, Muaro Jambi, 36361, Indonesia 


\section{PENDAHULUAN}

Pesantren dan kiai adalah dunia yang tak habis-habisnya untuk dipelajari dan digali. Sebagian orang mengatakan bahwa ia bagaikan mata air yang terus memancarkan kesegaran, mengalir dan mengalir seakan tak mengenal musim dan juga sebagian lagi mengatakan ia laksana bintangbintang yang jauh tak tercapai, tapi enak dipandang karena suatu bangsa patut bersyukur, jika di dalamnya masih terdapat bintang-bintang, apalagi yang kejora yaitu seorang kiai (Thoha, 2003). Pondok pesantren biasanya dikenal sebagai tempat belajar mengajar dengan pengetahuan yang terkait berbagai hal mengenai nilai-nilai keagamaan Islamiah yang turut menyediakan fasilitas sebagai tempat bermalam dengan mengaharuskan selama proses belajar mengajar para santri untuk menetap.

Pesantren sebagai lembaga pendidikan yang menjadi bagian penting sistem pendidikan nasional perlu memiliki standar mutu yang jelas dan terarah. Mutu dianggap sebagai bagian yang sangat penting, sebab pada dasarnya mutu menunjukkan kelebihan dari salah satu produk bila dibandingkan dengan produk lain yang tidak memiliki mutu. Peningkatan mutu merupakan cara maupun usaha dari berbagai lembaga-lembaga baik yang menghasilkan produk berupa barang atau jasa.

Peningkatan mutu tidak hanya dilakukan oleh lembaga yang menghasilkan produk berupa barang, tetapi juga lembaga yang menghasilkan produk jasa salah satunya adalah dunia pendidikan. Mutu merupakan aktivitas yang sangat penting dalam organisasi, karena meningkatkan mutu bisa dikatakan merupakan tugas yang paling sering dihadapi lembaga manapun. Pendidikan yang bermutu adalah menjadi harapan dan tujuan seluruh stakeholder pendidikan. Setiap orang pastinya cenderung lebih meminati mencari ilmu pada institusi yang bermutu baik. Lembaga maupun organisasi harus bisa bersaing dengan dalam hal peningkatan mutu sehingga tidak ditinggalkan dan mampu bersaing dengan lembaga lain.

Mutu pendidikan pesantren merupakan ukuran terhadap sesuatu yang diharapkan tercapai dan suatu produk atau layanan bagi para pelanggan yang ada. Pesantren yang bermutu adalah yang memiliki standar yang jelas dan telah disepakati bersama. Dengan demikian, pendidikan pesantren dikatakan 
bermutu bila orientasi mutu pendidikan yang terdiri dari input, proses dan output dapat terpenuhi dengan baik. Dalam menjalankan sebuah lembaga pendidikan pasti diperlukan seorang pemimpin atau manajer yang dapat mengatur, membimbing dan mengarahkan lembaga tersebut pada tujuan dari lembaga didirikan. Peran seorang pemimpin sangat berpengaruh di pondok pesantren pemimpinnya biasa disebut pengasuh atau kiai.

Kiai sebagai seorang pemimpin diharapkan memiliki kelebihankelebihan daripada orang yang dipimpinnya. Oleh karena itu, pemimpin nantinya selalu berhadapan dengan orang lain dalam konteks sosial, maka ia harus memiliki karakteristik ataupun ciri-ciri pribadi seorang pemimpin. Dalam kaitannya dengan perilaku yang tampak pada diri pemimpin, maka tidak terlepas dari sifat-sifat yang dimiliki oleh pemimpin tersebut. Sebab antara perilaku dan sifat yang melekat pada seorang pemimpin tidak bisa dipisahkan. Dengan demikian, mempelajari perilaku pemimpin sama artinya dengan mempelajari perilaku pemimpin sama artinya dengan mempelajari sifat-sifat yang harus dimiliki oleh pakar psikologi dan pakar organisasi dalam mengkaji kepemimpinan dengan cara mengenali karakteristik sifat atau ciriciri pemimpin yang berhasil.

Di pondok pesantren Zulhijah, kiai dalam hal ini berperan sebagai seorang penentu dan memotivator dalam menciptakan kebijakan dengan melakukan musyawarah bersama pihak-pihak dalam lingkup pondok pesantren. Pondok pesantren Zulhijjah juga berfokus pada Sekolah Menengah Pertama (SMP) dan Sekolah Menengah Atas (SMA) yang berdiri di bawah naungan pondok pesantren, sehingga pondok pesantren zulhijjah tidak mengajarkan tentang akhirat saja, melainkan mempelajari tentang dunia juga, agar mampu bersaing dengan lembaga pendidikan yang lainnya. Seorang kiai sebagai pemimpin pesantren harus mampu mengikuti perkembangan zaman yang mampu memahami strategi yang tepat untuk digunakan saat ini agar mampu meningkatkan mutu pendidikan.

\section{METODE}

Penelitian ini menggunakan metode deskriptif kualitatif. Pengumpulan data kualitatif dilakukan melalui observasi, wawancara, dan dokumentasi. Dalam penelitian ini, peneliti menggunakan teknik purposive sampling, yaitu teknik pengambilan sampel sumber data dengan pertimbangan tertentu, 
misalnya orang tersebut dianggap paling tahu tentang apa yang diharapkan, atau mungkin sebagai penguasa sehingga akan memudahkan peneliti menjelajahi objek/situasi sosial yang diteliti (Sugiyono, 2010). Analisis data menggunakan teknik triangulasi pengujian kreadibilitas diartikan sebagai pengecekan data dari berbagai sumber dengan berbagai cara, dan berbagai waktu (Sugiyono, 2013).

\section{HASIL PENELITIAN DAN PEMBAHASAN}

Kepemimpinan dalam sebuah lembaga pendidikan merupakan salah satu faktor terpenting, karena maju mundur, berkembang tidaknya lembaga tergantung dari bagaimana seorang pemimpin mengelola lembaga pendidikan tersebut. Salah satu unsur pemimpin di sebuah lembaga pondok pesantren adalah adanya seorang pengasuh atau kiai.

Pondok Pesantren Zulhijjah memiliki seorang pemimpin atau lebih sering didengar dengan sebutan pengasuh di bawah pimpinan Drs. KH. Lohot Hasibuan dan KH. Parlindungan Hasibuan. Beliau merupakan sosok pemimpin yang teladan, bijaksana dan peduli terhadap semua warga pesantren. Selain sebagai pengasuh Pondok Pesantren Zulhijjah beliau juga merupakan tokoh agama dan juga seorang ulama di Provinsi Jambi khususnya di Kabupaten Batanghari.

Ada 4 (empat) peran kiai dalam meningkatkan mutu pendidikan, pertama, kiai sebagai educator. Peran kiai sebagai edukator tentunya memiliki kemampuan untuk membimbing guru, peserta didik, mengembangkan tenaga kependidikan, mengikuti perkembangan iptek, dan memberi contoh mengajar. Peran kepemimpinan sebagai edukator dalam kepemimpinan pondok pesantren dalam meningkatkan mutu pendidikan di Pondok Pesantren Zulhijjah mencakup tiga hal, yaitu: a) memiliki kemampuan sebagai tenaga pendidik dalam menyusun program pembelajaran berdasarkan kurikulum. Kiai memilki kemampuan memberi arahan, penentuan, dan pelaksanaan dalam program pembelajaran tersebut. Dalam pembentukan program pembelajaran sebagai seorang pimpinan tertinggi di Pondok Pesantren Zulhijjah tindakan pendidikan yang diterapkan tidak terlepas dari kebijakan kurikulum pendidikan saat ini dengan tidak terlepas memandang kepada target visi berupa "menciptakan santri yang mampu menjadi kader 
ulama yang berakhlakul karimah, nasional, serta berakidah ahli Sunnah waljama'ah," serta misi "mempersiapkan santri yang berkepribadian Imdonesia, beriman, bertakwa kepada Allah SWT, unggul dan berkualitas serta beraqidah ahli Sunnah waljama'ah;" b) mengklasifikasikan/melakukan pemetaan kemampuan peserta didik. Pemetaan kemampuan peserta didik berupa kebijakan dan proses untuk melakukan pengumpulan, pengolahan, analisis data dan informasi tentang batas kemampuan dalam pengelompokan pembagian pertiap standar dari kemampuan peserta didik tersebut. Selanjutnya dari hasil observasi peneliti, klasifikasi/pemetaan yang dilakukan pihak lembaga pendidikan pesantren Pondok Pesantren Zulhijjah lebih dominan kepada pembagian kelas dan pengikut sertaan peserta didik dalam kontribusi terhadap kegiatan perlombaan yang diadakan baik di dalam maupun luar lingkungan pondok pesantren sehingga capaian dari santri unggulan akan tercapainya pula peningkatkan mutu pendidikan pada ponpes tersebut. Klasifikasi/pemetaan yang akan di bentuk berdasarkan kemampuan peserta dengan capaian standar santri unggulan yang didapati dari hasil tes, misalkan berupa kegiatan pemahaman ilmu agama dan kefasihan/kelancaran membaca ayat suci Al-Quran. Dari hasil penilaian tersebut santri yang memiliki akan diberikan kelas unggulan atau akselerasi yang tepat/sesuai; dan c) mengembangkan kemampuan tenaga pendidik. Pengembangan kemampuan tenaga pendidik merupakan tindakan memotivasi dan mendorong tenaga pendidik agar terciptanya minat mengajar yang lebih dan penambahan pemahaman ilmu pengetahuan dalam pemberian bahan ajar. Edukasi dalam pengembangan kemampuan tenaga pendidik dimaksudkan mampu menciptakan penyampain bahan ajar yang lebih baik, sehingga lebih mudah diterima oleh santri di Ponpes Zulhijjah melalui metode belajar berupa teori maupun praktek dilapangan langsung. Dorongan yang diberikan dari pihak lembaga pendidikan Pondok Pesantren Zulhijjah berdasarkan persetujuan/usulan langsung oleh pimpinan ponpes tersebut, berupa pemberian dukungan materi dan non materi kepada tenaga pendidik yang akan tingkat pendidikannya ke jenjang pendidikan yang lebih tinggi sehingga secara tidak langsung mampu meningkatkan mutu pendidikan di Pondok Pesantren Zulhijjah.

Kedua, kiai sebagai administrator. Kiai sebagai administrator memiliki hubungan yang sangat erat dengan berbagai aktivitas pengelolaan administrasi yang bersifat pencatatan, penyusunan, dan pendokumenan seluruh program 
sekolah. Pondok Pesantren Zulhijjah memiliki 3 (tiga) cakupan khusus yang dianjurkan oleh Pimpinan Pondok Pesantren Zulhijja, selanjutnya akan diembankan atau ditugaskan kepada penanggung jawab bagian administrasi, antara lain: a) mengadakan pendataan. Pengadaan kegiatan pendataan merupakan suatu kegiatan proses, cara dan pembuatan data dalam rangka mendata segala kebutuhan terkait ruang lingkup lembaga pendidikan Pondok Pesantren Zulhijjah. Pendataan berupa data pendidik dan kependidikan, santri, keuangan dan sarana dan prasana yang terkait dengan Pondok Pesantren Zulhjjah; b) memutakhirkan data. Memuktakhirkan data maksudnya adalah kegatan mengupdate atau pembaruan terhadap data yang tersedia. Misalkan pada santri yang baru memasuki lingkungan Pondok Pesantren Zulhijjah pada tingkatan kelas 3 (tiga) akan di masukkan kedalam pembagian data santri dikelas tiga dan dilakukan pengecekkan kembali apakah sesuai dengan abjad dan kriteria santri yang menduduki pada kelas tersebut; dan c) melakukan perkembangan pendataan. Pemberlakuan pengembangan data pada Pondok Pesantren Zulhijjah, berupa cakupan kegiatan sebagai berikut: 1) pengisian data, dalam pengisian data terkait tenaga pendidik dan kependidikan serta santri berupa identitas (nama, alamat, tempat tanggal lahir, pendidikan terakhir, dan lainnya); dan b) Data emis, data emisa berupa mendata data terkait lembaga pendidikan dala 1 (satu) kali pendataan, lengkap dan memenuhi semua kebutuhan berbagai pihak. Pengadministrasian yang dilakukan oleh pihak penanggung jawab bagian administrasi agar terciptanya ketertiban administrasi sebagai pendukung peningkatan mutu pendidikan di Pondok Pesantren Zulhijjah.

Ketiga, kiai sebagai manajer. Kiai sebagai manajer di pondok pesantren setidaknya memiliki kemampuan dan kapabilitas dalam mengelola lembaga pendidikan agar tercapainya peningkatkan mutu pendidikan di pondok pesantren. Tindakan pimpinan Pondok Pesantren Zulhijjah sebagai seorang manajer memiliki 2(dua) bagian penting dalam kemanajerialnya yaitu: a) motivasi, yang diberikan berupa kegiatan menumbuh kembangkan minat dan pemahaman tenaga pendidik dan kependidikan serta santri di Pondok Pesantren Zulhijjah. Contohnya pada tenaga pendidik yang akan atau sedang melanjutkan tingkatkan pendidikannya baik di S1 maupun S2 diberikan bantuan berupa materi maupun materi oleh lembaga pendidikan Pondok Pesantren Zulhijjah; dan b) evaluasi, yang dilakukan dalam peningkatan mutu 
pendidikan oleh pimpinan ponpes yaitu dengan meninjau dari hasil keunggulan santri sejauh mana capaian yang telah diperoleh selama proses pemberian bahan ajar berlangsung. Salah satu contohnya melihat hasil dari nilai raport santri di Pondok Pesantren Zulhijjah.

Keempat, kiai sebagai supervisor. Kiai sebagai supesrvisor diketahui disini lebih kepada bergerak dalam melakukan pembinaan terhadap rekan kerja terkait kepentingan untuk peningkatan mutu pendidikan yang diberlakukan melalui kegiatan rapat sebagai tindakan berupa aspirasi/masukan dari tiap warga Pondok Pesantren Zulhijjah. Dalam pembinaan yang dilakukan pimpinan pondok pesantren terkait meningkatkan mutu pendidikan di Pondok Pesantren Zulhijjah turut memberikan aspresiasi berupa reward/penghargaan bagi tenaga pendidik dan kependidikan yang mampu mengemban tugasnya dengan baik dan maksimal. Hal ini merupakan bentuk penciptaan semangat kerja lebih baik oleh pimpinan Pondok Pesantren Zulhijjah.

Hal-hal yang dilakukan pimpinan untuk pesantren sendiri adalah terus memperbaiki serta memenuhi sarpras yang dibutuhkan dan untuk para guru selalu mengupayakan agar para guru guru sejahtera bersama yaitu dengan cara menaikkan gaji secara merata. Pimpinan selalu memikirkan bahwasanya kesejahteraan para guru itu lebih penting daripada hal-hal lainnya. Kiai juga berharap alumni pondok pesantren zulhijjah mampu memberikan warna kehidupan bagi masyarakat provinsi Jambi khususnya, baik dari ilmu sosial terutama di bidang ilmu agama. Alumni zulhijjah diharapkan mampu memberikan sumbangsih pemikiran terhadap kemajuan daerah dan menjadi kader-kader ulama yang akan memimpin umat di masa yang akan datang.

\section{SIMPULAN}

Kiai memiliki 4 (empat) peran dalam meningkatkan mutu pendidikan, yaitu: 1) Kiai sebagai edukator mampu melaksanakan kegiatan: a) peningkatan kemampuan sebagai tenaga pendidik dalam menyusun program pembelajaran berdasarkan kurikulum, b) mengklasifikasikan/melakukan pemetaan kemampuan peserta didik, dan c) mengembangkan kemampuan tenaga pendidik; 2) Kiai sebagai administrator dengan melakukan: a) mengadakan Pendataan, b) memutakhirkan data, dan c) melakukan perkembangan pendataan; 3) Kiai sebagai manajer mampu memotivasi dan mengevaluasi; dan 
4) Kiai sebagai supervisor. Upaya yang dilakukan kiai dalam meningkatkan mutu pendidikan Pondok Pesantren Zulhijjah, yaitu mengupayakan kesejahteraan guru dan memberikan sumbangsih pemikiran terhadap kemajuan daerah dan mampu menjadi kader-kader ulama yang akan memimpin umat di masa yang akan datang.

Mutu pendidikan pondok pesantren Zulhijjah terdiri dari 3 (tiga) hal, yaitu: a) input, dalam penginputan penerimaan santri hanya memiliki kemahiran khusus dalam melantunkan lafaz Al-Quran; b) proses, dalam proses peningkatan mutu pendidikan di pondok pesantren mendasar kepada 3 (tiga) hal penting yaitu 1) penempatan tenaga pendidik/kependidikan yang sesuai kriteria, 2) penerapan kurikulum terbaru, dan 3) pemberian metode pengetahuan yang efektif; dan c) output, output di pondok pesantren terhadap peningkatan mutu pendidikan salah satunya berupa pencapaian hasil belajar santri dengan nilai hasil lulusan tertinggi dan santri mampu melanjutkan pendidikan hingga ke luar negara Indonesia.

\section{REFERENSI}

Akhyar. (2007). Konseling Islami Kyai dan Pesantren. Yogyakarta: elSAQ Press. Djamas. (2008). Dinamika Pendidikan Islam di Indonesia Pasca Kemerdekaan. Jakarta: PT Raja Grafinda Persada.

Djuhana. (2007). Kepemimpinan Kiai-Jawara. Banten: Badan Litbang \& Diklat Departemen Agama RI.

Kompri. (2018). Manajemen E Kepemimpinan Pondok Pesantren. Jakarta: Prenadamedia Group.

Mahmud, Hilal. (2015). Administrasi Pendidikan (Menuju Sekolah yang Efektif). Makasar: Penerbit Aksara Timur.

Meleong, J Lexi. (2007). Metode penelitian kualitatif. Bandung: PT. Remaja Rosdakarya.

Saleh. dkk. (2017). Islam dan Mutu Pendidikan Empowering Sekolah Dasar Islam Terpadu. Jambi: PUSAKA Jambi.

Sugiyono. (2010), Metode Penelitiaan Pendidikan; Pendekatan Kuantitatif, Kualitatif dan RED). Bandung: Alfabeta.

Susanto. (2016). Produktivitas Sekolah; Teori dan Praktik di Tingkat Satuan Pendidikan. Bandung: Alfabeta.

Thoha. (2003). Runtuhnya Singgasana Kiai NU Pesantren dan Kekuasaa:

Pencarian Tak Kunjung Usai. Yogyakarta: Kutub.

Wijaya, dkk. (2015). Kepemimpinan Berkarakter. Sidoarjo: Brilian Internasional. 